\section{Neuropeptide Y and Epilepsy}

William F. Colmers, Dr. rer. nat. and Bouchaïb El Bahh, Ph.D.

Department of Pharmacology, University of Alberta,

Edmonton, Alberta, Canada

It is a central tenet of the epilepsy field that seizures result from the imbalance of excitation over inhibition (1). The bulk of excitation is mediated by the neurotransmitter glutamate, whereas inhibition results mainly from the actions of $\gamma$-aminobutyric acid $(G A B A)$. In the neocortex and hippocampus, the intrinsic sources of $G A B A$ are the interneurons, which lately have come under intense scrutiny. It has become clear that a large number of distinct types of interneurons can be differentiated in part by the array of neuropeptides they coexpress (cf. 2). Evidence is emerging that the neuropeptide complement of interneurons plays important roles in the way that interneurons regulate excitability. Here we discuss what is known about the relation of one well-characterized neuropeptide, neuropeptide $Y(N P Y)$, and epilepsy in experimental animals and humans, and suggest possible roles for the receptors as targets for the control of excessive excitation in epilepsy.

$\mathrm{N}$ europeptide Y (NPY) is a 36-amino acid peptide made by neurons throughout the brain and by other secretory cells of the body. NPY has been associated with a number of physiologic processes in the brain, including the regulation of energy balance, memory and learning, and epilepsy. In the hippocampus and neocortex, NPY is made by neurons that almost all express $\gamma$-aminobutyric acid (GABA). Many NPYcontaining interneurons also coexpress somatostatin (3). NPY receptors are densely concentrated in the strata radiatum and oriens of Ammon's horn of rats (3) and humans (4).

Early investigations focused on the actions of NPY in the hippocampus. We (5-7,) and others (8) observed that application of NPY to freshly prepared slices of rat hippocampus maintained in vitro potently and selectively reduced synaptic excitation mediated by glutamate release (Fig. 1A). Further

Address correspondence to William F. Colmers, M. D., Department of Pharmacology, University of Alberta 9-36 MSB, Edmonton, AB, Canada T6G 2H7. E-mail: William.colmers@ualberta.ca

Epilepsy Currents Vol. 3, No. 2 (March/April) 2003 pp. 53-58

Blackwell Science Inc.

(C) American Epilepsy Society work showed that the action of NPY was highly selective, inhibiting only excitatory inputs onto pyramidal cell throughout Ammon's horn in the rat, but not affecting either synaptic inhibition $(7,8)$ or inputs to dentate granule cells $(9)$, despite the very high levels of NPY in the molecular layer of the dentate (10). The receptor or receptors involved in these actions belong to the $G$ protein-coupled superfamily (11; see later).

Detailed studies of the action of NPY were consistent with an entirely presynaptic site in rat hippocampus. Specifically, in neurons whose glutamatergic inputs were suppressed by NPY, the peptide did not affect the postsynaptic responses to glutamate application $(6,12)$. Consistent with this, the release of glutamate from hippocampal slices was shown to be suppressed by NPY (13). Further studies showed that NPY suppressed $\mathrm{N}$-type $\mathrm{Ca}^{2+}$ currents at presynaptic terminals in neuronal cultures (14) and N-, P/Q-, and other types of $\mathrm{Ca}^{2+}$ currents in presynaptic terminals of freshly prepared hippocampal slices (15). Once the sites and mechanisms of action were clear, the next question was what role NPY actually played in the physiology and pathophysiology of the hippocampus.

It appears that elevated activity in hippocampal circuitry, such as that accompanying epileptiform discharges, results in increased NPY expression in interneurons and dentate granule cells, but that prolonged overstimulation in some epilepsy models and in humans ablates NPY (and other) interneurons. Thus several laboratories determined that NPY peptide and messenger RNA (mRNA) expression was increased in epilepsy models in vivo (16-18). At about the same time, it was reported that NPY/GABA interneurons in the hippocampus were selectively ablated in rat epilepsy models in vivo $(19,20)$ and in epilepsy patients (21), although it was recently questioned whether NPY cells are indeed selectively vulnerable in human epilepsy (22). Further work suggested that NPY is expressed ectopically in dentate granule cells of the rat after increased activity (23-25), although this does not appear to be the case after prolonged chronic activity $(22,25)$. However, the increased expression appears to be genuine, because in hippocampal slices prepared from fully kindled rats, the release of NPY is greatly increased over that of controls (26). Whereas some of this release arises from NPY interneurons, the majority is most likely to arise from the massive expression of NPY in the mossy fibers (26). Thus work by several laboratories suggested that NPY might be involved in the hippocampal response to epileptogenesis. 
A

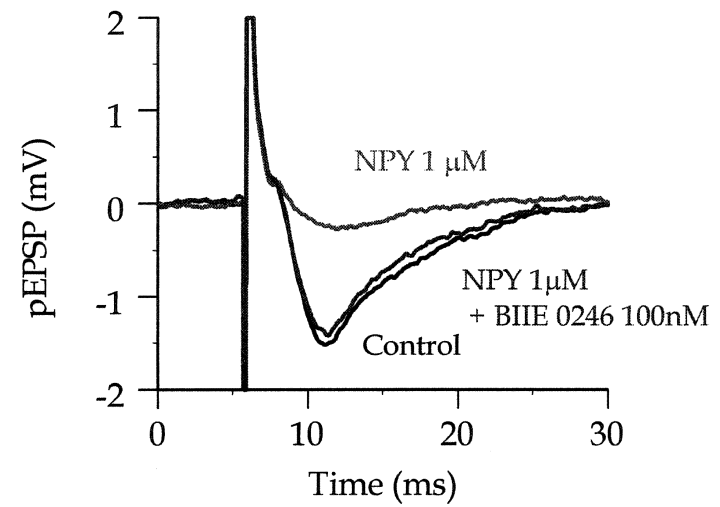

B
Control

$\Delta$

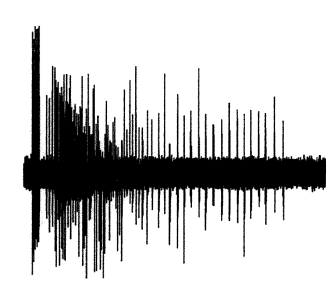

NPY

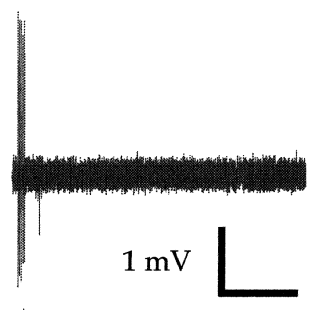

$10 \mathrm{~s}$
NPY + BIIE0246

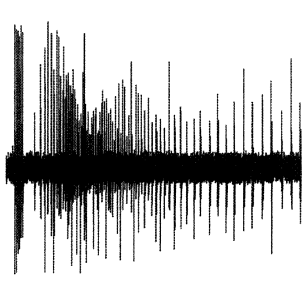

$\Delta$
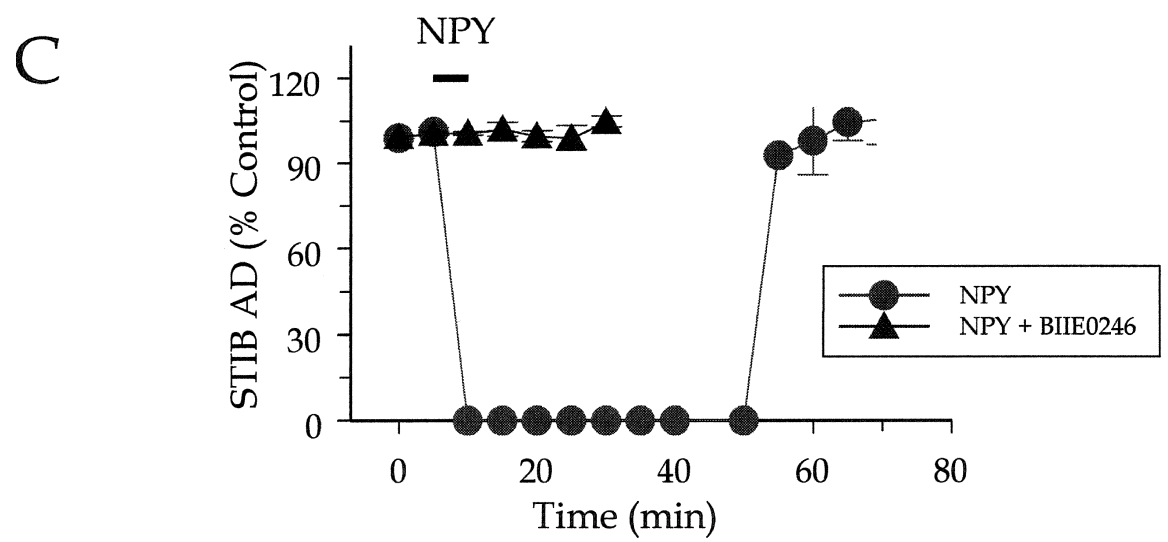

FIGURE 1 Actions of neuropeptide $Y$ (NPY) and a $Y_{2}$ antagonist in rat hippocampal slices. A: effect of npy on the population excitatory postsynaptic potential (pEPSP) evoked by electrical stimulation of stratum radiatum in area CA2, recorded extracellularly in area CA1. Black trace, control response; red trace, response in the presence of 1 mM NPY; blue trace, response to NPY in the presence of the $Y_{2}$-receptor antagonist BIIE $0246(100 \mathrm{~nm})$. B: Effect of npy on primary afterdischarges (18 $A D s)$ in the stimulus train-induced bursting (STIB) model in rat hippocampal slice. Extracellular recording from area $\mathrm{CA} 3$ shows tonic-clonic 18 $A D$ in control (left trace) in the presence of NPY (300 nm) (center trace), and in $300 \mathrm{~nm}$ npy after pretreatment with BIIE $0246(100 \mathrm{nM})$. C: time course of the inhibition of the $18 \mathrm{AD}$ by NPY $(300 \mathrm{~nm})$ in the absence (red circles) and presence (blue triangles) of BIIE $0246(100 \mathrm{nM})$. (B and C modified from ref. 53, with permission).
Coupled with the observations of inhibitory NPY actions on glutamate release, the hypothesis emerged that NPY normally controlled excitability in the hippocampus. This was tested in the following ways.

\section{Epilepsy Models In Vitro}

Several models mimic features of the acute pathophysiology of epilepsy in vitro. Interictal bursting caused by removal of extracellular $\mathrm{Mg}^{2+}$ (27-29) or by blockade of $\mathrm{GABA}_{\mathrm{A}}$ receptors with picrotoxin $(27,29)$ are sensitive to actions of NPY. Similarly, in the in vitro models of ictal activity such as the stimulus train-induced bursting (STIB; 30) and related models (31), the primary afterdischarge mimics the tonic- clonic characteristics of limbic seizures and responds to clinically effective concentrations of anticonvulsants (AEDs) that are effective on complex partial seizures (32). NPY, peptide YY (PYY), and the $\mathrm{Y}_{2}$ receptor-selective agonist, $\left[a \mathrm{ax}^{5-24}\right] \mathrm{NPY}$, potently inhibited the afterdischarge (29; see later for details about NPY receptors), whereas the $Y_{1}$ and $Y_{5}$ receptor-preferring ligand, Leu ${ }^{31}$, Pro ${ }^{34} \mathrm{NPY}$ was without effect on the afterdischarge in this model $(29,33)$, suggesting the importance of the $\mathrm{Y}_{2}$ receptor in NPY action (see later). Finally, NPY has been tested in slices of the frontal neocortex against seizure activity induced by a $0-\mathrm{Mg}^{2+}$ solution. In this preparation, NPY also suppressed seizure activity, but the results differed from those in hippocampus in two ways: first, that it appeared to be a $Y_{1}$ / $\mathrm{Y}_{5}$ receptor mediating the effect; and second, that the duration 
and frequency of individual interictaform bursts were reduced $(34,35)$. The reason for these differences in the actions of NPY in the hippocampus is unclear. However, overall, the actions of NPY in hippocampal epilepsy models were consistent with a presynaptic site of action.

\section{Epilepsy Models In Vivo}

In several models of epilepsy in vivo, the anti-epileptic effects of NPY have been studied. When rat brain $\mathrm{GABA}_{\mathrm{A}}$ receptors are blocked in vivo with picrotoxin, NPY injection into hippocampal area CA1 inhibited the epileptic behavior induced by picrotoxin pretreatment (36). In a kainic acid model in vivo, NPY injection into the lateral ventricle suppresses motor seizures activity and greatly shortens the kainate-induced ictal EEG recorded in dentate gyrus and CA3 $(37,38)$. Similar results were observed with seizures induced by hippocampal rapid kindling $(37,38)$. The prolonged infusion of NPY into the hippocampus of classically kindled rats also delayed the progression of hippocampal kindling, whereas anti-NPY antibodies applied the same way accelerated the progress of kindling (39).

NPY application in vivo also reduces seizure susceptibility in mice $(40,41)$. Thus in vivo results in several different models of epilepsy or, really, epileptogenesis, are consistent with a powerful antiexcitatory, antiepileptogenic action of NPY.

\section{NPY Receptors and Antiepileptic Actions}

Several receptors for NPY have been identified and cloned, the most prominent of which in the hippocampus and neocortex are the $\mathrm{Y}_{1}, \mathrm{Y}_{2}$, and $\mathrm{Y}_{5}(11)$. Considerable effort has gone into identifying the receptor or receptors involved in the antiepileptic actions of NPY. In vitro, early work with fragments of NPY suggested that the pharmacologic profile of the presynaptic actions of NPY in hippocampal area CA1 fit that of the $\mathrm{Y}_{2}$ receptor (42). However, it became clear as more receptors were discovered and characterized that these agonist fragments were not adequately specific. Nevertheless, results from in vivo work with the first available antagonist, the $\mathrm{Y}_{1}$ antagonist BIBP 3226, were intriguing, as they suggested that the activation of the $Y_{1}$ receptor was proconvulsant, and blockade of $Y_{1}$ receptors was anticonvulsant (43). Unfortunately, different antagonists needed for the unambiguous testing of the inhibitory role of NPY in the regulation of excitability either have not been available or their physical properties make them not amenable to in vivo experiments. The role of endogenous NPY in the regulation of excitability in vivo has therefore been explored by using alternate approaches.

\section{Genetic Manipulation of NPY and Receptor Expression}

A rat strain made to overexpress NPY transgenically showed a significant reduction in the number and duration of EEG seizures induced by kainic acid or electrical kindling and exhibited a decrease in the susceptibility to epileptogenesis, correlated with a strong expression of NPY mRNA in the hippocampus (44). Thus an increase in the normal expression of NPY results in a decreased susceptibility to seizures.

Consistent with this, the absence of NPY in mice increases their susceptibility to seizures. Thus in mice in which the NPY gene has been genetically ablated, mild, spontaneous seizures were reported, and their seizure thresholds to PTZ were reduced (41). In another study with these NPY knockout animals, latency and threshold for kainate-mediated seizure induction was identical with that of wild-type littermates, but the NPY knockouts progressed to an uncontrollable status epilepticus and died if not pretreated with NPY (40). Thus evidence from these experiments suggests that endogenous NPY plays a critical role in regulation of excitability. However, these experiments did little to address the nature of the receptor(s) involved.

Mice lacking the $\mathrm{Y}_{5}$ receptor were tested for seizure threshold and susceptibility (45). $\mathrm{Y}_{5}$-receptor knockout mice do not exhibit spontaneous epileptic activity; however, they revealed an enhanced sensitivity to kainic acid-induced seizures (45). Furthermore, slices prepared from $\mathrm{Y}_{5}$ knockout animals were insensitive to the actions of NPY $(45,46)$. Based on these results, it appeared that the $\mathrm{Y}_{5}$ receptor was the dominant receptor in antiepileptic actions of NPY. A further interesting observation was that the $\mathrm{Y}_{5}$ knockout mice were less susceptible to death in response to kainate injections. As an aside, the lethality of seizures may partly be related to the background genetic strain of the mice carrying the knockout, as $\mathrm{Y}_{5}$-receptor knockouts in an inbred SV129 line were much more susceptible to status epilepticus than were $\mathrm{Y}_{5}$ knockout animals bred to a mixed C57BL/6J $\times$ SV129 background (45).

These results were somewhat surprising, based on the high levels of $Y_{2}$ relative to $Y_{5}$ receptors in the hippocampus (47), and the significant induction of $Y_{2}$ receptor mRNA and expression (48). Although there is certainly evidence for presynaptic $\mathrm{Y}_{5}$ receptors in the hippocampus, there is no evidence that these receptors are capable of suppressing limbic seizure activity in the STIB model (49).

Our laboratory recently tested this question by using a newly developed antagonist to the $\mathrm{Y}_{2}$ receptor, BIIE 0246 (50), which profoundly reduced the presynaptic response to $\mathrm{NPY}$ and to the selective $\mathrm{Y}_{2}$-receptor agonist, $\left[\mathrm{ahx}^{5-24}\right] \mathrm{NPY}$ (51). Indeed, $30 \mathrm{n} M$ BIIE 0246 reduced the effect of NPY in area CA1 of hippocampal slices to $40 \%$ of control levels (52; 
Fig. 1A). The antagonism did not appear to be competitive in hippocampal slices, but the antagonist does behave competitively on $Y_{2}$ receptors on membranes $(50,53)$, so the apparent noncompetitive action could be attributed to the lipophilic properties of the antagonist (52). Most important, in STIB preparations in which NPY potently suppresses epileptiform activity, BIIE 0246 completely and potently blocks the effect of NPY (52; Fig. 1B and C). Furthermore, a potent and highly selective $\mathrm{Y}_{5}$ agonist was entirely without effect on the epileptiform activity in the STIB model, either alone or in the presence of BIIE 0246 (52). More recently, our laboratory has begun experiments on mice lacking the $\mathrm{Y}_{2}$ receptor. Preliminary results suggest that neither NPY, $\mathrm{Y}_{2}$ agonists, nor $\mathrm{Y}_{5}$ agonists have any effect either on the population excitatory postsynaptic potential (pEPSP) or the epileptiform discharge in the STIB model in $Y_{2}$ knockout animals (54).

Clearly NPY can have potent actions in models of epilepsy, but the ultimate test of its relevance to epilepsy is in the human. We $(55,56)$ and others (57) examined the NPY effects on neurons from epilepsy patients. NPY had a potent and prolonged presynaptic inhibitory effect on excitatory synaptic transmission in human dentate gyrus, similar to the actions reported in Ammon's horn of the rat. The pharmacology of NPY receptors in the human may be more complex than that in the rat, but preliminary evidence suggests the presence at least of $\mathrm{Y}_{2}$ receptors (56). It would be of considerable interest for potential theraputic applications to determine whether the NPY receptors in human dentate gyrus are on sprouted mossy fibers, or whether they are on conventional inputs to dentate granule cells.

Overall, then, NPY and its receptors have intriguing properties for an endogenous anticonvulsant system in the hippocampus. Unlike that of many inhibitory transmitters, the action of NPY is restricted to presynaptic sites in Ammon's horn and is specific to terminals releasing excitatory amino acids onto principal neurons in the hippocampus. The plasticity of the NPY system in response to elevated activity can generally be considered adaptive. Thus NPY expression and that of the $Y_{2}$ receptor are upregulated with elevated activity, whereas expression of the proconvulsant $Y_{1}$ receptor decreases. Furthermore, the ectopic expression of NPY in dentate granule cells, after even mild elevations in activity, can be considered adaptive, as the mossy fibers have a very sensitive presynaptic response to NPY. NPY also acts in epileptic human brain tissue, arguably the ultimate pharmacologic target in this field of research.

However, a number of very important questions remain. Which receptors are the most important in the antiepileptic actions of NPY? How can the conflicting data regarding the receptors be reconciled? What does NPY do in the neocortex and other areas related to seizure generation and spread? Most important from a therapeutic standpoint, can a selective, preferably nonpeptide agonist be generated that will activate the correct receptor in the CNS? These and many other questions are being actively studied, and interesting answers will continue to emerge.

\section{Acknowledgments}

We thank the Canadian Institutes for Health Research, The University of Alberta Hospitals Foundation, and the Human Frontiers Science Program Organization. W.F.C. is a Medical Scientist of the Alberta Heritage Foundation for Medical Research.

\section{References}

1. Moshe SL. Mechanisms of action of anticonvulsant agents. Neurology 2000;55(5 suppl 1):S32-S40.

2. Freund TF, Buzsaki G. Interneurons of the hippocampus. Hippocampus 1996;6:347-470.

3. Hendry SHC. Organization of neuropeptide $Y$ neurons in the mammalian central nervous system. In: Colmers WF, Wahlestedt C, eds. The Biology of Neuropeptide Y and Related Peptides. Totowa, NJ: Humana Press, 1993:65-135.

4. Furtinger S, Pirker S, Czech T, Baumgartner C, Ransmayr G, Sperk G. Plasticity of $Y_{1}$ and $Y_{2}$ receptors and neuropeptide $Y$ fibers in patients with temporal lobe epilepsy. J Neurosci 2001;21:58045812.

5. Colmers WF, Lukowiak K, Pittman QJ. Neuropeptide Y reduces orthodromically evoked population spike in rat hippocampal CA1 by a possibly presynaptic mechanism. Brain Res 1985;346:404-408.

6. Colmers WF, Lukowiak K, Pittman QJ. Presynaptic action of neuropeptide Y in area CA1 of the rat hippocampal slice. J Physiol 1987; 383:285-299.

7. Colmers WF, Lukowiak K, Pittman QJ. Neuropeptide Y action in the rat hippocampal slice: site and mechanism of presynaptic inhibition. J Neurosci 1988;8:3827-3837.

8. Haas HL, Hermann A, Greene RW, Chan-Palay V. Action and location of neuropeptide tyrosine $(\mathrm{Y})$ on hippocampal neurons of the rat in slice preparations. J Comp Neurol 1987;257:208-215.

9. Klapstein GJ, Colmers WF. On the sites of presynaptic inhibition by neuropeptide $Y$ in rat hippocampus in vitro. Hippocampus 1993;3: 103-111.

10. Köhler C, Eriksson L, Davies S, Chan-Palay V. Neuropeptide Y innervation of the hippocampal region in the rat and monkey brain. J Comp Neurol 1986;244:384-400.

11. Michel MC, Beck-Sickinger AG, Cox H, Doods HN, Herzog H, Larhammar D, Quirion R, Schwartz T, Westfall T. XVI International Union of Pharmacology recommendations for the nomenclature of neuropeptide Y, peptide YY, and pancreatic polypeptide receptors. Pharmacol Rev 1998;50:143-150.

12. McQuiston AR, Colmers WF. Neuropeptide $Y$ does not alter NMDA conductances in CA3 pyramidal neurons: a slice-patch study. Neurosci Lett 1992;138:261-264.

13. Greber S, Schwarzer C, Sperk G. Neuropeptide Y inhibits potassium-stimulated glutamate release through $\mathrm{Y}_{2}$ receptors in rat hippocampal slices in vitro. Br J Pharmacol 1994;113:737-740.

14. Toth PT, Bindokas VP, Bleakman D, Colmers WF, Miller RJ. Mech- 
anism of presynaptic inhibition by neuropeptide $\mathrm{Y}$ at sympathetic nerve terminals. Nature 1993;364:635-639.

15. Qian J, Colmers WF, Saggau P. Inhibition of synaptic transmission by neuropeptide $\mathrm{Y}$ in rat hippocampal area CA1: modulation of presynaptic $\mathrm{Ca}^{2+}$ entry. J Neurosci 1997;17:8169-8177.

16. Marksteiner J, Sperk G. Concomitant increase of somatostatin, neuropeptide $\mathrm{Y}$ and glutamate decarboxylase in the frontal cortex of rats with decreased seizure threshold. Neuroscience 1988;26:379-385.

17. Marksteiner J, Sperk G, Maas D. Differential increases in brain levels of neuropeptide $\mathrm{Y}$ and vasoactive intestinal polypeptide after kainic acid-induced seizures in the rat. Naunyn Schmiedebergs Arch Pharmacol 1989;339:173-177.

18. Sloviter RS. Chemically defined hippocampal interneurons and their possible relationship to seizure mechanisms. In: Chan-Palay V, Kohler C, eds. The Hippocampus: New Vistas, Neurology and Neurobiology. New York: Alan R. Liss, 1989:52:443-461.

19. Sloviter RS. Calcium-binding protein (calbindin-D28k) and parvalbumin immunocytochemistry: localization in the rat hippocampus with specific reference to the selective vulnerability of hippocampal neurons to seizure activity. J Comp Neurol 1989;280:183-196.

20. Sloviter RS. Permanently altered hippocampal structure, excitability, and inhibition after experimental status epilepticus in the rat: the "dormant basket cell" hypothesis and its possible relevance to temporal lobe epilepsy. Hippocampus 1991;1:41-66.

21. de Lanerolle NC, Kim JH, Robbins RJ, Spencer DD. Hippocampal interneuron loss and plasticity in human temporal lobe epilepsy. Brain Res 1989;495:387-395.

22. Sundstrom LE, Brana C, Gatherer M, Mepham J, Rougier A. Somatostatin- and neuropeptide Y-synthesizing neurones in the fascia dentata of humans with temporal lobe epilepsy. Brain 2001;124:688697.

23. Goodman JH, Sloviter RS. Cocaine neurotoxicity and altered neuropeptide $\mathrm{Y}$ immunoreactivity in the rat hippocampus; a silver degeneration and immunocytochemical study. Brain Res 1993;616: 263-272.

24. Schwarzer C, Sperk G, Samanin R, Rizzi M, Gariboldi M, Vezzani A. Neuropeptides-immunoreactivity and their mRNA expression in kindling: functional implications for limbic epileptogenesis. Brain Res Brain Res Rev 1996;22:27-50.

25. Causing CG, Makus KD, Ma Y, Miller FD, Colmers WF. Selective upregulation of T alpha 1 alpha-tubulin and neuropeptide $Y$ mRNAs after intermittent excitatory stimulation in adult rat hippocampus in vivo. J Comp Neurol 1996;367:132-146.

26. Rizzi M, Monno A, Samanin R, Sperk G, Vezzani A. Electrical kindling of the hippocampus is associated with functional activation of neuropeptide Y-containing neurons. Eur J Neurosci 1993;5:15341538.

27. Klapstein GJ, Colmers WF. On the sites of presynaptic inhibition by neuropeptide $\mathrm{Y}$ in rat hippocampus in vitro. Hippocampus 1993;3: 103-111.

28. Bijak M. Inhibitory effect of neuropeptide y on epileptiform activity in the frontal cortex and hippocampus in vitro. Pol J Pharmacol 1995; 47:461-463.

29. Klapstein GJ, Colmers WF. Neuropeptide Y suppresses epileptiform activity in rat hippocampus in vitro. J Neurophysiol 1997;78:16511661.

30. Stasheff SF, Bragdon AC, Wilson WA. Induction of epileptiform activity in hippocampal slices by trains of electrical stimuli. Brain Res 1985;344:296-302.

31. Stanton PK, Jones RS, Mody I, Heinemann U. Epileptiform activity induced by lowering extracellular $\left[\mathrm{Mg}^{2+}\right]$ in combined hippocampal-entorhinal cortex slices: modulation by receptors for norepinephrine and $N$-methyl-d-aspartate. Epilepsy Res 1987;1:53-62.

32. Clark S, Wilson WA. Brain slice model of epilepsy: neuronal networks and actions of antiepileptic drugs. In: Faingold CL, Fromm GH, eds. Drugs for Control of Epilepsy: Actions on Neuronal Networks Involved in Seizure Disorders. Boca Raton: CRC Press, 1992: 89-123.

33. Bindokas VP, Lee CC, Colmers WF, Miller RJ. Changes in mitochondrial function resulting from synaptic activity in the rat hippocampal slice. J Neurosci 1998;18:4570-4587.

34. Bijak M. Neuropeptide Y suppresses epileptiform activity in rat frontal cortex and hippocampus in vitro via different NPY receptor subtypes. Neurosci Lett 1999;268:115-118.

35. Bijak M. Neuropeptide Y reduces epileptiform discharges and excitatory synaptic transmission in rat frontal cortex in vitro. Neuroscience 2000;96(3):487-94.

36. Smialowska M, Bijak M, Sopala M, Tokarski K. Inhibitory effect of NPY on the picrotoxin-induced activity in the hippocampus: a behavioural and electrophysiological study. Neuropeptides 1996;30:712.

37. Woldbye DP, Madsen TM, Larsen PJ, Mikkelsen JD, Bolwig TG. Neuropeptide Y inhibits hippocampal seizures and wet dog shakes. Brain Res 1996;737:162-168.

38. Woldbye DP, Larsen PJ, Mikkelsen JD, Klemp K, Madsen TM, Bolwig TG. Powerful inhibition of kainic acid seizures by neuropeptide Y via $Y_{5}$-like receptors. Nat Med 1997;3:761-764.

39. Reibel S, Larmet Y, Carnahan J, Marescaux C, Depaulis A. Endogenous control of hippocampal epileptogenesis: a molecular cascade involving brain-derived neurotrophic factor and neuropeptide Y. Epilepsia 2000;41(suppl 6):S127-S133.

40. Baraban SC, Hollopeter G, Erickson JC, Schwartzkroin PA, Palmiter RD. Knock-out mice reveal a critical antiepileptic role for neuropeptide Y. J Neurosci 1997;17:8927-8936.

41. Erickson JC, Clegg KE, Palmiter RD. Sensitivity to leptin and susceptibility to seizures of mice lacking neuropeptide Y. Nature 1996; 381:415-421.

42. Colmers WF, Klapstein GJ, Fournier A, St-Pierre S, Treherne KA. Presynaptic inhibition by neuropeptide $\mathrm{Y}$ in rat hippocampal slice in vitro is mediated by a $\mathrm{Y}_{2}$ receptor. Br J Pharmacol 1991;102:4144.

43. Gariboldi M, Conti M, Cavaleri D, Samanin R, Vezzani A. Anticonvulsant properties of BIBP3226, a non-peptide selective antagonist at neuropeptide $\mathrm{Y}_{1}$ receptors. Eur J Neurosci 1998;10:757-759.

44. Vezzani A, Michalkiewicz M, Michalkiewicz T, Moneta D, Ravizza T, Richichi C, Aliprandi M, Mule F, Pirona L, Gobbi M, Schwarzer C, Sperk G. Seizure susceptibility and epileptogenesis are decreased in transgenic rats overexpressing neuropeptide Y. Neuroscience 2002; 110:237-243.

45. Marsh J, Baraban SC, Hollopeter G, Palmiter RD. Role of the $\mathrm{Y}_{5}$ neuropeptide Y receptor in limbic seizures. Proc Natl Acad Sci U S A 1999;96:13518-13523.

46. Baraban SC. Antiepileptic actions of neuropeptide $\mathrm{Y}$ in the mouse hippocampus require $\mathrm{Y}_{5}$ receptors. Epilepsia 2002;43(suppl 5):9-13.

47. Dumont Y, Jacques D, Bouchard P, Quirion R. Species differences in the expression and distribution of the neuropeptide $Y_{1}, Y_{2}, Y_{4}$, and $\mathrm{Y}_{5}$ receptors in rodents, guinea pig, and primates brains. J Comp Neurol 1998;402:372-384.

48. Vezzani A, Moneta D, Mule F, Ravizza T, Gobbi M, French-Mullen J. Plastic changes in neuropeptide $\mathrm{Y}$ receptor subtypes in experimen- 
tal models of limbic seizures. Epilepsia 2000;41(suppl 6):S115S121.

49. Ho MWY, Beck-Sickinger AG, Colmers WF. Neuropeptide $\mathrm{Y}_{5}$ receptors reduce synaptic excitation in proximal subiculum, but not epileptiform activity in rat hippocampal slices. J Neurophysiol 2000; 83:723-734.

50. Doods H, Gaida W, Wieland HA, Dollinger H, Schnorrenberg G, Esser F, Engel W, Eberlein W, Rudolf K. BIIE0246: a selective and high affinity neuropeptide Y Y(2) receptor antagonist. Eur J Pharmacol 1999;384:R3-R5.

51. Cabrele C, Beck-Sickinger AG. Molecular characterization of the ligand-receptor interaction of the neuropeptide Y family. J Pept Sci 2000;6:97-122.

52. El Bahh B, Cao JQ, Beck-Sickinger AG, Colmers WF. Blockade of neuropeptide $Y_{2}$ receptors and suppression of NPY's anti-epileptic actions in the rat hippocampal slice by BIIE0246. Br J Pharmacol 2002;136: 502-509.

53. Dumont Y, Cadieux A, Doods H, Pheng LH, Abounader R, Hamel
E, Jacques D, Regoli D, Quirion R. BIIE0246, a potent and highly selective non-peptide neuropeptide $\mathrm{Y} \mathrm{Y}_{2}$ receptor antagonist. $\mathrm{Br} \mathrm{J}$ Pharmacol 2000;129:1075-1088.

54. El Bahh B, Herzog HH, Beck-Sickinger AG, Doods H, Colmers WF. $Y_{2}$ receptors are necessary and sufficient for anticonvulsant presynaptic action of NPY in rat and mouse hippocampus. Soc Neurosci Abst 2002.

55. Colmers WF, Pronchuk N, Torok-Both C, Ho M, Aronyk K, McKean J, Snyder T, Sinclair DB, Javidan M, Beck-Sickinger AG. Neuropeptide $\mathrm{Y}_{2}$ and other receptors inhibit synaptic excitation in epileptic human brain. Epilepsia 1997;38(suppl 8):12.

56. Colmers WF, Pronchuk N, Wheatley M, Javidan M, McKean J, Sinclair DB, Snyder TJ. The NPY Y 2 receptor antagonist, BIIE0246, suppresses the presynaptic actions of NPY on synaptic excitation in human dentate granule cells. Epilepsia 2000;41(suppl 7):15.

57. Patrylo R, van den Pol AN, Spencer DD, Williamson A. NPY inhibits glutamatergic excitation in the epileptic human dentate gyrus. J Neurophysiol 1999;82:478-483. 